\title{
DEVELOPMENTAL ASPECTS OF THE FORMATION OF THE COMMON AGRICULTURAL POLICY OF THE EU IN THE CONTEXT OF ITS INDIVIDUAL REFORMS
}

\author{
[Vývojové aspekty formovania Spoločnej pol'nohospodárskej politiky \\ EÚ v kontexte jej jednotlivých reforiem]
}

\author{
Ivana Kravčáková Vozárová ${ }^{1}$, Monika Daňová ${ }^{2}$ \\ ${ }^{1}$ Prešovská univerzita v Prešove, Fakulta manažmentu, Konštantínova 16, 08001 Prešov \\ Email: ivana.kravcakova.vozarova@unipo.sk \\ ${ }^{2}$ Prešovská univerzita v Prešove, Fakulta manažmentu, Konštantínova 16, 08001 Prešov \\ Email: monika.danova@unipo.sk
}

\begin{abstract}
The Common Agricultural Policy has a major impact on the development of the agricultural sector in the countries of the European Union because this sector is significantly regulated in comparison with the sector of industry or services. A considerable part of the professional community deals with the question how the agricultural sector reacts to such form of regulation. The paper provides a more comprehensive synthesis of knowledge about the formation and development of the Common Agricultural Policy in order to create a comprehensive overview of the theoretical formation of this policy from the perspective of domestic and foreign authors.
\end{abstract}

Keywords: Common Agricultural Policy, historical development, European Union, reforms.

JEL classification: E60, F68, Q18

Doručeno redakci: 27.3.2017; Recenzováno: 1.4.2017; 26.4.2017; Schváleno k publikování: 31.5.2017

\section{Úvod}

Podl’a poznatkov doterajších štúdií je Spoločná pol’nohospodárska politika EÚ významnou oblast'ou z pohladu regulácie trhu. Regulácia pol’nohospodárskeho sektora je často obhajovaná práve koncepciou špecifickosti samotného odvetvia $\mathrm{v}$ dôsledku jeho nestálosti či rôznych geografických obmezení. Názory na jej formovanie v kontexte jednotlivých reforiem, samotný charakter ako i význam jej existencie sú rôzne. Okrem rozdielov v názoroch na samotný zmysel vzniku tejto politiky a jej dominantné postavenie z hl'adiska rozpočtu EÚ a prijatej legislatívy, variabilita sa vyskytuje i v názoroch na jednotlivé nástroje a intenzitu ich vplyvu na jednotlivé členské štáty EÚ. V príspevku skúmame formovanie tejto politiky s využitím syntézy poznatkov a jednotlivých opatrení formovaných v priebehu jej jednotlivých revízií. Význam problematiky fungovania Spoločnej pol’nohospodárskej politiky EÚ narastá, i ked' publikované názory a sformovanie rôznych prístupov dokumentujú rešpektovanie jej významu a jej parciálne riešenia už v historickom kontexte jej samotného formovania.

Príspevok prináša podrobnější prehl’ad poznatkov o vzniku a vývoji Spoločnej pol’nohospodárskej politiky EÚ s ciel’om vytvorenia komplexného teoretického prehl'adu formovania tejto politiky z pohl'adu prístupov domácich a zahraničných autorov. Pri písaní príspevku sme použili metódy logické: metódu syntézy, analýzy, metódu normatívneho a deskriptívneho prístupu ako aj metódu komparácie. Analýza bola použitá pri samotnom štúdiu dostupnej domácej a zahraničnej literatúry a následnom spracovaní prehl’adného vývoja tejto politiky. Metóda syntézy bola použitá pri spájaní čiastkových poznatkov zistených vo fáze 
analýzy do jedného celku ako aj pri formulácii záverov z analýzy vyplývajúcich. Významnou metódou bola aj metóda komparácie, prostredníctvom porovnania názorov domácich a zahraničných autorov na problematiku vývoja formovania tejto politiky ako aj porovnania najvýznamnejších výsledkov jej jednotlivých reforiem.

\section{Vznik regulácie agrárneho trhu}

Efektívne fungovanie pol'nohospodárskeho sektora je nevyhnutnou súčast'ou efektívne fungujúcej ekonomiky každého štátu. Pol'nohospodársky sektor hral vo vývoji integračného procesu $\mathrm{v}$ západnej Európe od začiatku mimoriadne dôležitú rolu. V období po druhej svetovej vojne krajiny neboli schopné zaist'ovat' svoju pol'nohospodársku produkciu a tak vznikla potreba vytvorit' účinný mechanizmus, ktorý by umožňoval plynulé dodávky potravín. Z toho vyplýva, že hlavné príčiny vzniku Spoločnej pol'nohospodárskej politiky mali predovšetkým ekonomický a politický dôvod (Smutka a kol. 2010, Fojtíková a Lebiedzik 2008). Spoločná pol'nohospodárska politika patrí medzi najvýraznejšie dôsledky európskeho integračného procesu, zjavne je aj najznámejšou aktivitou Spoločenstva a taktiež asi najviac diskutovanou. Pri tvorbe tejto politiky sa prihliadalo ku špecifickým rysom, ktoré pol'nohospodársky sektor má. Na rozdiel od priemyselnej výroby, kde sa dá relatívne presne stanovit' objem výroby v prípade pol'nohospodárskej produkcie je to inak. Pol'nohospodárska produkcia je silne ovplyvňovaná prírodnými podmienkami, ako sú napr. živelné pohromy, záplavy či obdobia sucha, ktoré sa nedajú predpokladat' a nedá sa voči nim ochránit' (Kučerová 2010, Fojtíková a Lebiedzik 2008).

\section{Zaistenie potravinovej bezpečnosti v Európe}

Toto obdobie je charakteristické predovšetkým formovaním spoločných názorov na potreby pol'nohospodárskeho sektora a formulovaním prvých spoločných postupov. Vzhl'adom $\mathrm{k}$ tomu, že Európa prešla pred týmto obdobím dvoma svetovými vojnami, ktoré zapríčinili stav nedostatočného zásobovania potravinami, bola pol'nohospodárska výroba chápaná ako strategické odvetvie. Primárnym ciel'om Spoločnej pol'nohospodárskej politiky EÚ tak bolo dosiahnutie sebestačnosti vo výrobe základných potravín ako strategických surovín. S týmto ciel'om tak korešponduje d'alší ciel' v podobe preferencie domáceho pol'nohospodárstva pred zahraničnými konkurentmi. Nakol'ko pol'nohospodárstvo tvorilo majoritný podiel na zamestnanosti vtedajšej spoločnosti, súčast'ou programu sa stala aj snaha o zabezpečenie postupného rastu dôchodkov pol'nohospodárov. Rozhodnutie o spoločnom riadení agrárneho sektora sa prijalo pri podpisovaní Rímskej zmluvy o založení EHS (v článkoch 32-33 hlavy II), ale základy Spoločnej pol’nohospodárskej politiky boli vypracované až v júli 1958 na konferencií v Strese. Tu sa zástupcovia členských štátov dohodli, že hlavným regulačným nástrojom bude cenová politika riadená Komisiou, ktorej smernice budú podliehat' schváleniu Rady ministrov. Boli tu tiež deklarované tri základné princípy Spoločnej pol'nohospodárskej politiky a to princíp jednoty trhu, preferencie domácej produkcie a princíp finančnej solidarity (Kučerová 2010). Ackrill (2008) tvrdí, že od konferencie v Strese prešla Spoločná pol'nohospodárska politika množstvom zmien. Jej prítomnost' však bola jednou z najvýznamnejších a najstabilnejších vlastností "európskeho projektu". Po zavedení cenovej podpory ako hlavného prostriedku na podporu príjmov pol'nohospodárskych podnikov sa klúčové prvky rozpočtového procesu EÚ spojili s rastúcou produkciou a prebytkami čo priviedlo SPP na cestu, ktorá neúprosne viedla k finančnej kríze.

V januári 1962 bol založený Európsky pol’nohospodársky záručný a usmerňovací fond (EAGGF), ktorý predstavoval základný nástroj pre financovanie pol'nohospodárskeho sektora. Spoločná pol'nohospodárska politika sa ukázala ako politika, ktorá dokázala naplnit' stanovené ciele, akými boli zvýšenie výroby, ako aj produktivity, stabilizácia trhov či 
potravinová bezpečnost'. Došlo aj $\mathrm{k}$ zvýšeniu medzinárodného obchodu $\mathrm{s}$ pol'nohospodárskymi výrobkami ako aj $\mathrm{k}$ ochrane farmárov pred fluktuáciou cien na svetových trhoch. Avšak v druhej polovici 60 . rokov sa západoeurópske štáty začali potýkat's problémom nadprodukcie niektorých pol'nohospodárskych komodít a $\mathrm{s}$ absolútnym rastom výdavkov na SPP. Poskytovanie dotácií sa spájalo s nespravodlivou a najmä nerovnomernou distribúciou medzi jednotlivé členské krajiny a farmárov. Pôvodne však tvorcovia tejto politiky neuvažovali o jej finálnej podobe, ale iba o prechodnom režime, ktorý bude po naplnení základných ciel’ov prehodnotený. Práve tento stav však späl k prvým reformným návrhom (Kučerová 2010, Harakal'ová 2013).

Európsky pol’nohospodársky komisár Sicco Mansholt vykonal v roku 1968 jedinečný pokus transformovat' vidiecke hospodárstvo vtedajšieho šest'členného Európskeho hospodárskeho spoločenstva. Komisia uverejnila provokatívne memorandum, v ktorom navrhla všeobecné pravidlá na urýchlenie štrukturálnych zmien $\mathrm{v}$ pol'nohospodárstve, vrátane poskytovania finančných stimulov na povzbudenie polovice pol'nohospodárskej populácie opustit' toto odvetvie. Nie je prekvapením, že tento plán vyvolal vášnivé protesty a tri smernice, ktoré boli nakoniec prijaté, boli ovel'a menej ambiciózne než pôvodné návrhy (Stead 2007). Tento plán, ktorý je známy aj ako Mansholtov plán predpokladal konsolidáciu fariem s redukciou piatich miliónov hektárov obrábanej pôdy a porovnatel'ným počtom malých pol'nohospodárov, ktorí by opustili odvetvie. To malo umožnit' vel'korysé náhrady, ktoré mali byt' časom vyplácané z dôvodu efektívnejšej pol'nohospodárskej výroby a zníženia nákladov na tzv. intervencie. $\mathrm{Na}$ základe týchto reformných opatrení mali tak pol'nohospodári možnost' získat' podporu na modernizáciu svojich fariem po vypracovaní a predložení ich rozvojového plánu, ktorý by preukázal rentabilitu vložených investícií. Mansholtov plán tiež kládol dôraz na vyššie odborné vzdelávanie, rekvalifikáciu a predčasný odchod do dôchodku pol'nohospodárov starších ako 55 rokov, ktorí sa vzdajú svojej pol'nohospodárskej pôdy v prospech mladej generácie (Harakal'ová 2013). Podl'a Fojtíkovej a Lebiedzik (2008) išlo vôbec o prvý pokus o reformu SPP, ktorý bol zameraný na zníženie počtu osôb zamestnaných v pol'nohospodárskom sektore ako aj na zvýšenie efektívnosti pol'nohospodárskej výroby. Tento pokus modernizovat' pol'nohospodársku výrobu však narazil na odpor záujmových skupín farmárov a preto bol ponechaný iba na vôl’u vlády jednotlivých členských krajín.

Od osemdesiatych rokov bola EÚ ešte úspešnejšia v plnení svojho ciel'a $\mathrm{v}$ dosahovaní sebestačnosti. Musela však odrazu zápasit's takmer trvalými prebytkami tých najdôležitejších pol'nohospodárskych komodít, z ktorých sa niektoré bud' vyvážali (pomocou dotácií) alebo sa museli uskladňovat' či dokonca likvidovat' $v$ rámci EÚ. Stále sa zvyšujúci objem pol'nohospodárskych platieb sa premietol do neúnosne vysokého podielu na výdajoch spoločného rozpočtu, kedy v roku 1980 dosiahli náklady na pol'nohospodársku politiku až 70 \% rozpočtu. Táto situácia si však vyžadovala určité zmeny (Kašt’áková 2012, Kučerová 2010). V roku 1984 došlo k uskutočneniu summitu vo Fontainebleau, kde boli prijaté zásadné rozhodnutia $\mathrm{v}$ oblasti zvýšenia príjmov ES a zároveň zníženia výdavkov na SPP. Princíp rozhodnutí spočíval $\mathrm{V}$ tom, že produkcia nad samotnú kvótu nemohla profitovat' $\mathrm{z}$ garantovaných cien. Došlo tak k spomaleniu dokonca zastaveniu rastu garantovaných cien a celý intervenčný systém sa tak stal menej automatický. Pôvodne sa hovorilo o tomto opatrení ako o prechodnom, platí však dodnes. Ďalší summit sa konal v roku 1985 v Bruseli. Toto stretnutie malo za ciel' opätovne zrevidovat' financovanie SPP, nakol'ko vd'aka neustále sa zvyšujúcim výdavkom na SPP sa Spoločenstvo dostalo na pokraj kolapsu. Materiál, ktorý sa označoval ako Delorsov balík bol tak pokusom o zníženie nákladov a zvýšenie príjmov Spoločenstva. Základnými opatreniami bolo znižovanie garantovaných cien jednotlivých pol'nohospodárskych produktov spolu s prijatím produkčných kvót, ktoré by obmedzili 
nadprodukciu. Týkalo sa to predovšetkým produkcie mlieka. Zaviedli sa stabilizátory takmer na všetky pol'nohospodárske výrobky, ktoré spočívali v automatickom znížení garantovaných cien po prekročení fixne stanovených objemov produkcie, tzv. maximálne garantované množstvá. V Delorsovej reforme sa prvýkrát prijali aj opatrenia, ktoré by umožňovali pol'nohospodárom prijat' kompenzácie $\mathrm{v}$ peňažnej podobe výmenou za úhorovanie pôdy. Dôležité je spomenút' aj vypracovanie Zelenej knihy Perspektívy Spoločnej pol'nohospodárskej politiky $\mathrm{v}$ roku 1985, čo bolo pokusom nadviazat' na dohodu z Fontainebleau. Hlavnou myšlienku tohto dokumentu bolo vytvorenie rovnováhy medzi príjmami a výdavkami Spoločenstva, avšak neúspešne. Tento dokument je ale považovaný za začiatok zmeny priorít SPP (Harakál'ová 2013). Reálne zmeny však priniesla až MacSharryho reforma $v$ roku 1992.

\section{Problém nadprodukcie a kompenzácie príjmov pol'nohospodárov}

Ako uvádza Kotulič a Adamišin (2010) prvú ucelenú reformu Spoločnej pol’nohospodárskej politiky EÚ predstavuje tzv. MacSharryho reforma, ktorá prebiehala v prvej polovici devät'desiatych rokov. Pokusy zvrátit' nepriaznivý stav vo výrobe v priebehu osemdesiatych rokov neviedli k odstráneniu nadprodukcie a boli považované za nedostatočné. Až do roku 1992 bola SPP vysoko cenovou politikou, v rámci ktorej spotrebitelia platili značnú čast' nákladov na dotovanie pol'nohospodárov prostredníctvom umelo vysokých spotrebitel'ských cien (Daugbjerg 2014). Túto reformu charakterizovali dve hlavné skutočnosti:

$>$ stanovenie nízkych cien strategických pol'nohospodárskych produktov;

$>$ kompenzácia dopadov zníženia týchto cien na príjmy pol'nohospodárov pomocou mechanizmu priamych platieb.

Kučerová (2010) tvrdí, že nutnost' revízie agrárnej politiky bola evidentná, nakol'ko náklady na jej financovanie rástli rýchlejšie než objem pol'nohospodárskej produkcie. Dôležitým aspektom bolo aj to, že zodpovednost' financovania ležala len na niekol'kých štátoch. Riešenie MacSharryho reformy spočívalo na jednej strane v prepojení poklesu cenových dotácií, na strane druhej v zaistení primeraných príjmov pol'nohospodárov. Išlo o kombináciu týchto nástrojov (Kučerová 2010, Lebiedzik a Tvrdoň 2007):

> zníženie intervenčných a prahových cien, čo predstavovalo aj samotný záväzok v rámci uruguajského kola;

$>$ zavedenie kompenzačných platieb pri redukcii výroby zaist'ujúce stabilný príjem $\mathrm{v}$ závislosti od vel'kosti obrábanej pôdy či vel'kosti stáda; nový systém podpory bol založený na tom, že tieto kompenzácie im budú vyplácané na hektár a výška kompenzácie sa v jednotlivých regiónoch líši v závislosti od priemernej produktivity v týchto regiónoch;

$>$ orientácia na obmedzovanie objemu výroby a to vrátane úhorovania rotujúceho či trvalého;

$>$ podpora predčasného odchodu do dôchodku (farmárov starších ako 55 rokov), v prípade ak umožnia zväčšovanie fariem a tým aj efektívnejšiu výrobu, tým, že prenechajú svoje hospodárstvo inému subjektu (pol’nohospodár tak obdrží ročné náhrady za každý hektár prenechanej pôdy, zvláštnu penzijnú podporu a d’alšie kompenzácie nezávislé na výmere pôdy, ktorej sa vzdal);

$>$ podpora alternatívneho využívania pol'nohospodárskej pôdy ako napr. zalesňovanie, rekreácia, turistika, atd'.

Hlavným ciel’om reformy bolo postupnými krokmi za využitia vyššie uvedených opatrení odstránit' rozdiely medzi vnútornou a svetovou cenou pol’nohospodárskej výroby a tým obmedzit' exportné dotácie. Táto skutočnost' však bola ale vo vel'mi úzkom vzt’ahu s 
nutnost'ou znížit' ceny a prispôsobit' objemy produkcie skutočnému dopytu. Táto reforma SPP sa však netýkala všetkých sektorov výroby, avšak zásadne ovplyvnila pestovanie obilnín a produkciu hovädzieho mäsa. V menšej miere ovplyvnila aj produkciu mlieka, masla, tabaku či jahňacieho mäsa. Uskutočnená reforma z roku 1992 sa považuje za prvý úspešný reformný krok v ponímaní Spoločnej pol’nohospodárskej politiky EÚ. Intervenčný mechanizmus sa stal pružnejší a taktiež došlo $\mathrm{k}$ stabilizácií výdavkov na SPP, ale $\mathrm{z}$ dlhodobého hl'adiska stále nedošlo k celkovej stabilizácií (Lebiedzik a Tvrdoň 2007). Tak ako sme už zhodnotili vyššie, túto reformu možno považovat' za úspešnú len z časti, nakol'ko stále nedošlo k odstráneniu finančnej náročnosti Spoločnej pol'nohospodárskej politiky EÚ. V roku 1997 Európska komisia navrhla reformu SPP v rámci dokumentu nazvanom Agenda 2000, ktorý zohl'adňoval všetky vyššie uvedené skutočnosti. Definitívna verzia reformy bola prijatá na zasadnutí Európskej rady v Berlíne v roku 1999 (Fojtíková a Lebiedzik 2008).

Reforma Agenda 2000 rozdelila SPP na dva piliere: podpora výroby a rozvoj vidieka. Zaviedlo sa niekol'ko opatrení na rozvoj vidieka vrátane diverzifikácie, zakladania skupín výrobcov a podpory mladých pol'nohospodárov. Pol'nohospodárskoenvironmentálne schémy sa stali povinnými pre každý členský štát, vzhl'adom na skutočnost', že situácia $\mathrm{v}$ členských štátoch mala charakteristiky, ktoré museli verejné orgány zohl'adňovat' s ciel'om orientácie na rozvoj a modernizáciu štruktúr, ale aj reguláciu trhov a zabezpečenia príjmov pol'nohospodárov (Avram and Radu 2008). Reforma obsahovala nasledujúce dielčie opatrenia (Fojtíková a Lebiedzik 2008, Kučerová 2010):

$>$ zníženie cenových podpôr u pol'nohospodárskych produktov, ako obilniny (o 15 \%), hovädzie mäso (o $20 \%$ ) a od roku 2005 taktiež u mlieka (o $15 \%$ ) s ciel'om zaistit' konkurencieschopnost' európskeho pol'nohospodárstva;

$>$ zaistenie primeranej životnej úrovne pol'nohospodárov, kedy príspevky k príjmom nie sú viazané na objem produkcie;

$>$ decentralizácia a zavedenie tzv. národných obálok, čo by do istej miery znamenalo prenesenie nielen realizačnej čiže výplatnej právomoci na národné orgány, ale tým pádom i rozhodovacie kompetencie;

$>$ podpora trhovej orientácie pol’nohospodárov $\mathrm{s}$ dopadom na účast' EÚ $\mathrm{v}$ medzinárodnom obchode s pol'nohospodárskou produkciou;

> väčší dôraz na nezávadnost' a kvalitu potravín, $v$ čom sa zohl'adňuje záujem spotrebitel’ov o zvýšenú ochranu životného prostredia a zachádzanie so zvieratami;

$>$ začlenenie ekologických ciel'ov do SPP;

$>$ starostlivost' o rozvoj vidieka s ciel'om zachovat' európske kultúrne dedičstvo.

Agenda 2000 bola výslovne založená na ekonomických, sociálnych a environmentálnych ciel'och $\mathrm{v}$ rámci novej prepracovanej sady ciel’ov pre SPP v súlade $\mathrm{s}$ požiadavkami Amsterdamskej zmluvy. Prioritou bolo dat' $\mathrm{v}$ nasledujúcich rokoch európskemu modelu pol'nohospodárstva konkrétnu podobu a zachovat' rozmanitost' pol'nohospodárskych systémov rozmiestnených po celej Európe, vrátane regiónov so špecifickými problémami. Dôležitým aspektom tejto reformy bolo zavedenie dovtedy novej politiky rozvoja vidieka, ako druhého piliera SPP. Táto nová politika mala podporovat' rad vidieckych iniciatív a zároveň pomáhat' pol'nohospodárom diverzifikovat', t.j. zlepšit' uvádzanie ich výrobkov na trh a reštrukturalizovat' svoje podniky (Európska komisia 2014a).

Kučerová (2010) tvrdí, že požiadavky tejto reformy nakoniec neboli dosiahnuté z mnohých dôvodov ako napr. pomalšieho zníženia cien u obilia, mlieka či hovädzieho mäsa. Hlavným dôvodom sa však zretel'ne stalo odmietnutie princípu národných obálok, tzn. spolufinancovanie jednotlivými štátmi, čo odmietlo predovšetkým Francúzsko, Španielsko a 
Grécko, teda štáty, ktoré najviac profitujú na algoritme platieb. "MacSharryho obdobie" prinieslo isté zmeny, hoci sa nejednalo o radikálne reformy, ale iba o slušný pokus o ich realizáciu. Výsledky viedli na jednej strane k rastu kompenzačných platieb, ale vd'aka tomu poklesol podiel cenových intervencií a podpôr. Problém spočíval v tom, že vel'ká čast' týchto kompenzácií išla do rúk najbohatších pol'nohospodárov či vlastníkov pôdy. Vo všeobecnosti išlo až $80 \%$ kompenzácií do rúk len $20 \%$ pol'nohospodárov, čo do značnej miery narúšalo plnenie ciel'a príjmovej stabilizácie farmárov. Došlo k presnému opaku, ktorý sa premietol do vyššej príjmovej diferenciácie pol'nohospodárov.

Kotulič a Adamišin (2010) uvádzajú, že v rámci regulácie produkcie a zabránenia jej opätovného hromadenia do zásob sa $\mathrm{v}$ nadchádzajúcich rokoch pokračovalo $\mathrm{v}$ reforme oddel'ovania podpory od produkcie. V roku 2003 bola vyhodnotená “Agenda 2000” a došlo k návrhu jej d’alšej revízie, v podobe reformy, ktorá zvykne byt' označovaná ako Fischlerova reforma, podl’a vtedajšieho európskeho komisára Hanza Fischlera.

\section{Formovanie politiky posledného desat'ročia}

V roku 2003 skončili v Luxemburgu rokovania Rady ministrov pol’nohospodárstva členských krajín EÚ (na ktorých sa zúčastnili aj ministri kandidátskych krajín), ktoré sa týkali radikálnej reformy SPP na budúcich 10 rokov. Išlo v poradí už o tretiu reformu, ktorá sa nazýva Fischlerova reforma (Lebiedzik a Tvrdoň 2007). Podl'a Kučerovej (2010) sa začali objavovat' rôzne prístupy k problémom. Od pasívneho očakávania Francúzska a Talianska ku snahe o zavedenie trhových princípov zo strany Vel'kej Británie, Švédska, Holandska či Nemecka.

Táto reforma však na rozdiel od predchádzajúcich reforiem zavádzala niekol'ko podstatných úprav, medzi ktoré môžeme zaradit' (Fojtíková a Lebiedzik 2008, Lebiedzik a Tvrdoň 2007, Kašt'áková 2012, Kotulič a Adamišin 2010):

$>$ horizontálna oblast':

- zrušenie závislosti platieb od objemu produkcie na farme tzv. "decoupling", prostredníctvom zavedenia jednotnej platby na farmu. Namiesto niekol'kých platieb získava pol'nohospodár len jednu platbu.

○ zavedenie systému “cross compliance”, ktorý znamená, že platby sú závislé na splnení určitých štandardov a nie na objeme produkcie. Zaviedlo sa celkovo 19 legislatívnych predpisov, ktoré upravujú oblast' ochrany životného prostredia, nezávadnost' a kvalitu potravín, udržiavanie pôdy v dobrom stave, atd'.

○ zavedenie "systému povinnej modulácie", ktorý sa týka fariem, ktorým sa poskytujú platby nad 5000 eur. Z týchto platieb tak pôjdu odvody na rozvoj vidieka. Tento systém sa nevzt'ahuje na nové členské krajiny dovtedy, kým sa ich priame platby nevyrovnajú tým v starých členských krajinách.

- možnost' využitia zjednodušeného postupu, t.j. systému SAPS novými členskými krajinami EÚ v prvých rokoch hospodárenia po vstupe do EÚ a až neskôr prejst' na uplatňovanie SPS.

○ zavedenie pol'nohospodárskeho poradenského systému, tzv. "auditu fariem”, kedy členské krajiny musia od roku 2007 ponúknut' farmárom dobrovol'ný poradenský systém. Opatrenie sa týka fariem, ktoré získavajú podporu viac než 15000 eur.

trhové opatrenia:

○ zavedenie systému "set aside", t.j. povinné ukladanie pôdy do kl'udu. Opatrenie sa týka $10 \%$ základnej výmery ornej pôdy po dobu 10 rokov a nevzt'ahuje sa na farmy s výmerou nižšou ako 20 ha a ekologických pol'nohospodárov.

○ asymetrické zníženie cien $\mathrm{v}$ odvetví produkcie mlieka, najmä zníženie intervenčnej ceny masla o 25 \% počas štyroch rokov; 
○ redukcia mesačných príplatkov v odvetví produkcie obilnín na polovicu, pri udržaní súčasnej intervenčnej ceny;

○ d’alšie trhové opatrenia v odvetví ryže, zemiakového škrobu, sušených krmív, orechov, či hovädzieho mäsa.

Podstatou Fischlerovej reformy bolo prevedenie priamych platieb do režimu jednotnej platby na pol'nohospodársky podnik a tým aj oddelenie od súčasnej výroby. Úrovne platieb pre jednotlivé pol'nohospodárske podniky boli založené na historických platobných nárokoch. Ciel'om modulácie bol presun finančných prostriedkov najmä do oblasti rozvoja vidieka znížením transferov tým farmám, ktoré dostávali najvyššiu podporu. Dôraz sa kládol aj na krížové plnenie zavedené v Agende 2000. Od Agendy 2000 boli členské štáty povinné prijat' opatrenia na zabezpečenie zlučitel'nosti pol'nohospodárskych činností s environmentálnymi požiadavkami (Arovuori a Yrjola 2015).

K 1.máju 2004 došlo k historicky najväčšiemu rozšíreniu EÚ až o desat' nových členských štátov strednej, východnej Európy a Stredomoria. Tieto štáty boli v porovnaní so starými členskými štátmi ekonomicky zaostalejšie. Išlo o krajiny s nižšou cenovou úrovňou a podporou do oblasti pol’nohospodárstva. Novým členským štátom sa tak v rámci Spoločnej pol'nohospodárskej politiky EÚ otvoril vstup na jednotný trh. Stanovil sa pre ne finančný rámec na roky 2004-2006 a zaviedol sa mechanizmus postupného zavádzania priamych platieb s možnost'ou spolufinancovania z národných zdrojov. Samotné rozšírenie EÚ o týchto 10 nových členských krajín znamenalo zvýšenie objemu ornej pôdy až o 70 mil. ha, zdvojnásobenie počtu pracovníkov v pol'nohospodárstve a prinieslo až o cca 100 mil. nových spotrebitel'ov (Harakál'ová 2013).

Podl'a Meyna (2008) bola v poslednom desat'ročí Spoločná pol'nohospodárska politika (SPP) podstatne reformovaná. Fischlerova reforma z roku 2003, ktorá oddelila pol'nohospodárske platby od produkcie a vytvorila nový fond pre rozvoj vidieka nastavila parameter aj pre následné reformy. Jednou z nich je aj reforma "Health Check SPP", ktorá pokračuje v tomto procese reforiem na obdobie 2009-2012, ale nemení režim obchodnej politiky EÚ pre pol'nohospodárske produkty. Komisia zahájila "Kontrolu zdravotného stavu SPP (t.j. Health Check SPP)" v roku 2007. Hlavným ciel'om kontroly stavu podl'a Meyna (2010) bolo:

$>$ ul'ahčit' systém platieb pol'nohospodárom a zefektívnit' ho;

$>$ prispôsobit' trhové nástroje pokračujúcemu procesu globalizácie;

$>$ začlenit' nové výzvy, ako je zmena klímy, hospodárenie s vodou a rastúci význam biopalív;

$>$ lepšie reagovat' na existujúce výzvy (napr. zachovanie biodiverzity).

Historicky prvá reforma pol'nohospodárskej politiky, o ktorej rozhodovali spoločne ministri a priamo volení poslanci Európskeho parlamentu dostala svoju konečnú podobu v podobe Reformy Spoločnej pol’nohospodárskej politiky EÚ 2014-2020. Rokovania medzi členskými štátmi o viacročnom finančnom rámci odrážali základné národné záujmy a týkali sa návrhov, ako napr. zníženie úrovne financovania SPP zo strany Spojeného královstva. Tu sa vzt’ah medzi Spojeným královstvom a Francúzskom javí ako inštruktívny. Pod tlakom vel'kého počtu euroskeptických konzervatívnych poslancov žiadala Vel'ká Británia v celkovom viacročnom finančnom rámci na nové obdobie aspoň zmrazenie, ak nie podstatné zníženie príspevkov na SPP. Aj ked' odchádzajúci prezident Sarkozy občas podporoval zmrazenie výdavkov, Francúzsko nesúhlasilo s Vel'kou Britániou v otázke rozsahu "škrtov". 
Celkovo sa dosiahol konsenzus stanoviska podpory rozpočtového obmedzenia, hoci tu existoval nesúhlas s rozsahom "škrtov". Hlavnú úlohu zohralo Nemecko, ktoré podporilo rozhodnutie v prospech stláčania výdavkov. Britská vláda tak predstavila viacročný finančný rámec ako významný diplomatický triumf, pokial' ide o zabezpečenie zníženia rozpočtu. V tomto celkovom kontexte dohoda o viacročnom finančnom rámci vo všeobecnosti zachovala pomer výdavkov medzi priamymi platbami/trhovými opatreniami v rámci prvého piliera a rozvojom vidieka a environmentálnej udržatel’nosti v rámci druhého piliera (Greer 2013).

Nová politika pokračuje pozdĺž zavedených reforiem, pohybujúc sa od podpory produktov $\mathrm{k}$ podpore výrobcov. Reaguje na tie výzvy a faktory (vid' obr. 1), ktorým musí dané odvetvie čelit'. Medzi ne môžeme zaradit' (Európska komisia 2013):

$>$ Ekonomické faktory zahŕňajú bezpečnost' potravín a globalizáciu, klesajúce tempo rastu produktivity, kolísanie cien, tlak na výrobné náklady v dôsledku vysokých cien vstupov a na zhoršujúce sa postavenie pol’nohospodárov $\mathrm{v}$ potravinovododávatel'skom ret'azci. Dragoi and Balgar (2013) tvrdia, že pol'nohospodárstvo EÚ v súčasnosti čelí konkurencieschopnejšiemu medzinárodnému trhu, pretože svetová ekonomika sa stáva viac integrovanou a obchodný systém je čoraz viac liberalizovaný. Preto je mimoriadne dôležité zvýšit' produktivitu a konkurencieschopnost' pol’nohospodárstva EÚ. Ked’že sa očakáva, že celosvetový dopyt po potravinách bude v budúcnosti neustále rást', EÚ by mala byt' schopná splnit' túto hlavnú požiadavku. $Z$ tohto dôvodu je pre pol'nohospodárstvo EÚ nevyhnutné neustále udržiavat' a zlepšovat' výrobnú kapacitu pri rešpektovaní záväzkov EÚ týkajúcich sa medzinárodného obchodu a súdržnosti politík v oblasti rozvoja pol’nohospodárstva.

> Faktory životného prostredia sa týkajú zdrojov účinnosti, kvality vody a pôdy a ohrozenia biotopov a biodiverzity. Je všeobecne akceptované, že potravinový model, ktorý sa $\mathrm{v}$ Európskej únii za posledných pät’desiat rokov realizuje je jedným z faktorov, ktoré prispeli k environmentálnej degradácií a klimatickým zmenám, ktoré ovplyvnili prirodzenú rovnováhu ekosystémov. V dôsledku toho sa reforma Spoločnej pol'nohospodárskej politiky zamerala na presmerovanie financovania (najmä v rámci systému priamych platieb) na podporu trvalo udržatel'ného pol'nohospodárstva (Dragoi and Balgar 2013).

> Teritoriálne faktory sa týkajú vidieckych oblastí, ktoré čelia demografickému, hospodárskemu a sociálnemu vývoju, vrátane vyluudňovania a premiestňovania podnikov. Dragoi and Balgar (2013) argumentujú, že vitálnost' a potenciál mnohých vidieckych oblastí sú nad’alej úzko späté s existenciou konkurencieschopného a dynamického pol'nohospodárskeho sektora, ktorý je prítažlivý pre mladých pol’nohospodárov. Táto situácia je charakteristická prevažne vo vidieckych oblastiach, kde primárny sektor tvorí približne $5 \%$ pridanej hodnoty a $16 \%$ pracovnej sily. Treba tiež poznamenat', že pol'nohospodárstvo zohráva dôležitú úlohu vo vidieckych oblastiach tým, že vytvára súvisiace hospodárske činnosti súvisiace so spracovaním pol’nohospodárskych výrobkov, cestovným ruchom a obchodom. Aj v mnohých regiónoch EÚ je pol'nohospodárstvo základom miestnych tradícií a sociálnej identity. 
Obrázok 1: Výzvy a ciele reformy SPP EÚ 2014 až 2020

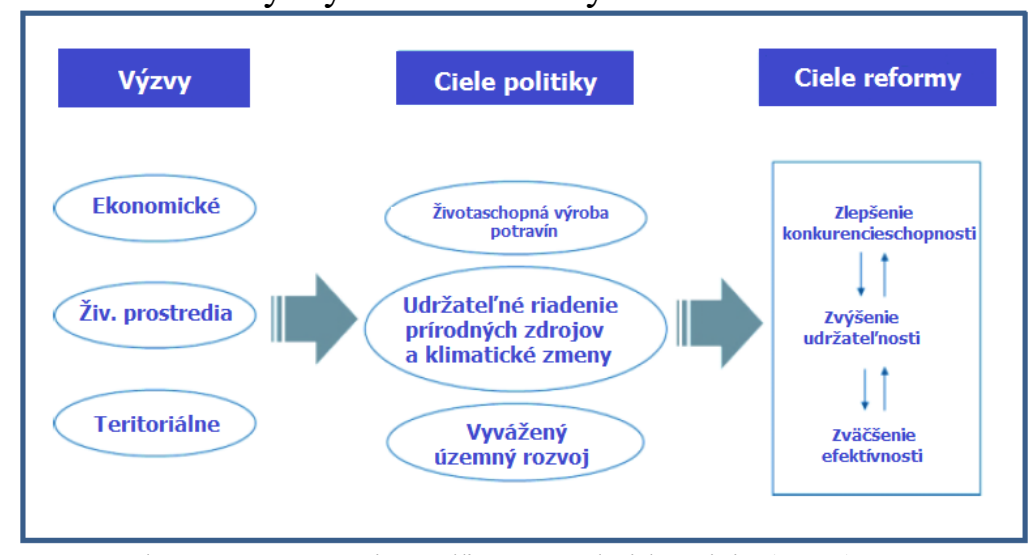

Zdroj: Vlastné spracovanie podl'a Európskej komisie (2013).

Nová reforma sa zaoberá štyrmi legislatívnymi oblast'ami, ktoré sú odrazom politickej dohody medzi Európskou komisiou, ministrami pol'nohospodárstva členských krajín a Európskym parlamentom. Ide o pravidlá týkajúce sa (Európska komisia 2014 a):

$>$ priamych platieb pre pol'nohospodárov;

$>$ trhových opatrení;

$>$ rozvoja vidieka;

$>$ horizontálnych otázok financovania a kontroly reformy.

Prvou legislatívnou oblast'ou sú priame platby, ktoré však treba lepšie prerozdelit', pretransformovat' a vymerat' tak, aby boli kritériá ich určenia založené na objektívnych a spravodlivých podmienkach. Priame platby predstavujú vel'kú čast' podpory poskytovanej pol'nohospodárom EÚ prostredníctvom Spoločnej pol'nohospodárskej politiky. Ich zameranie na zvýšenie a stabilizáciu príjmov pol'nohospodárskych podnikov je dobré známe avšak aj napriek tomu sú empirické dôkazy o tejto závislosti nedostatočné (Harakál'ová 2013, Severini a kol. 2016). Podpory by mali byt' zacielené na aktívnych pol'nohospodárov. Faktom je, že oddelené priame platby pol'nohospodárom boli zavedené v Európskej únii vo forme režimu jednotnej platby (SPS) v roku 2005. Reforma Spoločnej pol'nohospodárskej politiky (SPP) po roku 2013 zmenila vykonávanie režimu SPS, ktorý má dôležité politické dôsledky pre EÚ. Medzi členskými štátmi EÚ z dôvodu rozdielov na trhoch s pozemkami a pozemkových predpisoch existujú významné rodziely. V EÚ-27 sa v priemere $53 \%$ pol'nohospodárskej pôdy prenajíma. Členské štáty $\mathrm{s}$ vysokým podielom prenajatých pozemkov (viac ako 70 \%) zahŕňajú Slovensko, Bulharsko, Českú republiku, Francúzsko, Belgicko, Maltu a Nemecko. Medzi členské štáty s nízkym podielom prenajatých pozemkov (menej ako $30 \%$ ) patria Dánsko, Írsko, Pol’sko a Portugalsko. Tieto rozdiely tak ovplyvňujú rozsah, v akom pol'nohospodári alebo nepol'nohospodárski vlastníci pozemkov zachytávajú tieto platby (Ciaian 2014).

Pokial' ide o trhové opatrenia, snahou je minimalizovat' percento takto vynaložených prostriedkov určených na SPP z rozpočtu EÚ. Kým v roku 1991 bolo na trhové opatrenia vynaložených až $92 \%$ prostriedkov určených na SPP v roku 2009 to bolo už len $7 \%$. Od roku 2014 môžu pol'nohospodári požiadat' o environmentálne platby, ktoré sa používajú na podporu ochrany prírodných zdrojov. Suma peňazí zaplatená na tieto účely predstavuje $30 \%$ celkovej sumy priamych platieb. Toto rozhodnutie vyvolalo reakcie pol'nohospodárov $\mathrm{v}$ niektorých európskych krajinách, pretože neberie do úvahy kritérium regionálnej špecifickosti. Kým v Nemecku súhlasili s 40 až $50 \%$, pre nové členské krajiny bolo navrhované percento príliš vysoké. Tento prístup poukazuje na to, že aj aj ked' je 
pol'nohospodárska politika spoločnou politikou, pokial' ide o platenie, existujú medzi členskými štátmi zjavné rozdiely (Kostic a kol. 2016).

Medzi najvýznamnejšie kroky tejto reformy môžeme podl'a Európskej komisie (2014b) zaradit':

$>$ rovnomernejšiu distribúciu priamych podpôr (efektívnejšie využitie rozpočtových zdrojov prostredníctvom spravodlivejších a lepšie cielených priamych platieb);

$>$ ekologizáciu (tzv. greening) priamych platieb (30\% budúcich priamych platieb bude podmienených plnením okruhu environmentálne vhodných postupov, ktoré pôjdu nad rámec krížového plnenia);

$>$ podporu pre aktívnych pol'nohospodárov (zdôvodnenú efektívnejším využitím prostriedkov SPP);

$>$ limitovanie (tzv. capping) priamych platieb pre najväčších pol'nohospodárov (primeraný a progresívny priebeh „stropu“ na úroveň príjmu priamych platieb pre najväčšie podniky);

$>$ politiku rozvoja vidieka zameranú na výsledky;

$>$ zjednodušený režim pre malých pol'nohospodárov (rozpočtovo neutrálne zjednodušené režimy podpory, ktoré podstatne znížia administratívnu zát’až farmárov);

$>$ trhové výdavky a krízové mechanizmy (reštrukturalizácia trhových opatrení v rámci $\mathrm{I}$. piliera a tvorba rezervy na krízy v pol’nohospodárstve, na riešenie krízových situácií či na rezervy na núdzovú pomoc).

V priebehu posledných pät'desiatich rokov prešla Spoločná pol'nohospodárska politika EÚ mnohými reformami, ktoré boli poháňané vnútornými aj vonkajšími faktormi ekonomickej, sociálnej ako aj politickej povahy. V prvých rokoch sa začali modifikácie hlavne z dôvodu negatívnych účinkov spoločnej politiky na európske hospodárstvo. Neskoršie sa dôvodom pre d'alšie reformy stali vonkajšie faktory, predovšetkým globálna liberalizácia obchodu a silný medzinárodný tlak proti pol'nohospodárskemu intervencionizmu. Súčasná reforma SPP je motivovaná hlavne faktormi vnútorného charakteru, vrátane tlaku na zníženie podielu $\mathrm{v}$ rozpočte EÚ, v ktorom výdavky na pol'nohospodárstvo a rozvoj vidieka majú stále podstatnú čast'. Okrem výdavkov na pol'nohospodárstvo musí Európska únia podporovat' aj iné dôležité politiky, ale v čase hospodárskej recesie, ked' majú mnohé členské štáty obrovský verejný dlh, to nie je l'ahká úloha. Avšak mali by sa zohl'adnit' aj vonkajšie faktory, z ktorých niektoré majú potenciálne silný vplyv na európske hospodárstvo, ako napríklad kolísanie cien na pol'nohospodárskych trhoch, neustále rastúci tlak na zachovanie životného prostredia či procesy liberalizácie globálneho obchodu (Tankosic a Stojsavljevic 2014).

\section{Záver}

Spoločná pol'nohospodárska politika (SPP) prešla $\mathrm{v}$ priebehu jej historického vývoja zásadnými zmenami. V prvej fáze bola prioritou potravinová sebestačnost' a druhá fáza bola jednoznačne orientovaná $\mathrm{k}$ odstráneniu nadprodukcie a kompenzácie príjmov pol'nohospodárov. Tretia etapa, ktorej sa týka aj vývoj Spoločnej pol'nohospodárskej politiky (SPP) po roku 2013 sa vyznačuje zmenami v pol'nohospodárskom odvetví a berie do úvahy užitočnost' spojenú $\mathrm{s}$ blahobytom $\mathrm{v}$ rámci životného prostredia a poskytovania verejných statkov.

Aj napriek mnohým zmenám a reformám je táto politika stále vel'mi diskutovanou oblast'ou aj v kontexte zmyslu jej samotnej existencie. Na jednej strane práve súčasná podoba priamych platieb je jedným z určujúcich faktorov neefektívneho využívania pol’nohospodárskych 
zdrojov, čo je $\mathrm{v}$ rozpore $\mathrm{s}$ hlavnými zásadami jednotného trhu Európskej únie. Na strane druhej je však oblast' pol'nohospodárstva neoddelitel'nou súčast'ou národného hospodárstva spoločnosti a na úrovni Európskeho spoločenstva má významnú úlohu pokial' ide o hospodársky rast či sociálnu udržatel'nost'. Pravdou je, že odvetvie pol'nohospodárskej výroby je silne ovplyvňované najmä takými faktormi, ktoré sa $\mathrm{v}$ iných odvetviach nezvyknú vyskytovat', teda či už samotnými prírodnými podmienkami ako aj špecifikami vo výrobných cykloch rastlinnej a živočíšnej výroby či charakterom a dostupnost'ou jednotlivých možností financovania. Avšak z pohl'adu dlhodobej perspektívy v tejto oblasti panuje názorová zhoda autorov, že budúcou výzvou pre pol’nohospodárstvo bude zvýšenie produktivity v rámci ochrany životného prostredia a spoločenskej zodpovednosti nakol'ko pol'nohospodári sú zodpovední za riadenie rozsiahlych oblastí európskeho územia a tým bezpochyby mimoriadne významnou mierou prispievajú k produkcii verejných statkov a služieb.

\section{Pod'akovanie}

Príspevok bol riešený v rámci projektu VEGA 1/0139/16 „Analýza determinantov a faktorov ovplyvňujúcich efektívnost' a konkurencieschopnost' subjektov hospodáriacich na pôde $\mathrm{V}$ Slovenskej republike“; a projektu KEGA 035PU-4/2016 „Mikroekonómia pre manažérov inovácia štruktúry, obsahu a spôsobu výučby predmetu“.

\section{Literatúra}

[1] ACKRILL, R., 2008. The CAP and its reform - half a century of change? EuroChoices, 7(2), 13-21. ISSN 1478-0917.

[2] AROVOURI, K. and T. YRJOLA, 2015. The impact of the CAP and its reforms on the productivity growth in agriculture. In: 147th EAAE Seminar: "CAP Impact on Economic Growth and Sustainability of Agriculture and Rural Areas". Sofia: The Institute of Agricultural Economics, s. 1-14.

[3] AVRAM, C. and R. RADU, 2008. European Union's Common Agricultural Policy: Evolution, Objectives, Challenges and Future Perspectives. Revista de Stiinte Politice, 20, 45-54. ISSN 1584-224X.

[4] CIAIAN, P., D. A. KANCS and J. SWINNNEN, 2014. The Impact of the 2013 Reform of the Common Agricultural Policy on Land Capitalization in the European Union. Applied Economic Perspectives and Policy, 36(4), 643-673. ISSN 2040-5790.

[5] DAUGBJERG, C., 2014. Explaining Reform and Reversal of the EU's Common Agricultural Policy, 1992-2013. In: ECPR General Conference. Glasgow: University of Glasgow, 1-17.

[6] DRAGOI, A. a C. BALGAR, 2013. The Future Of Common Agricultural Policy And The Challenges Of Europe 2020 Strategy. Global Economic Observer, 1(1), 93-100. ISSN 2343 - 9750.

[7] EURÓPSKA KOMISIA., 2014(a). The history of the CAP. [online]. [vid. 2016-08-16]. Dostupné z: http://ec.europa.eu/agriculture/cap-history/index_en.htm

[8] EURÓPSKA KOMISIA., 2014(b). Legal proposals for the CAP after 2013. [online]. [vid. 2016-08-16]. Dostupné $\quad$ : http://ec.europa.eu/agriculture/cap-post-2013/legalproposals/index_en.htm

[9] EURÓPSKA KOMISIA., 2013. Overview of CAP Reform 2014-2020 (Aricultural Policy Perspectives Brief No. 5/Dec1ember 2013). [online]. [vid. 2016-08-27]. Dostupné z: http://ec.europa.eu/agriculture/cap-post-2013/ 
[10] FOJTÍKOVÁ, L. a M. LEBIEDZIK, 2008. Společné politiky Evropské unie. Historie a současnost se zaměřením na Českou republiku. 1. vyd. Praha: C.H.BECK. ISBN 978-80717-9939-9.

[11] GREER, A., 2013. The common agricultural policy and the EU budget: Stasis or change? European Journal of Government and Economics, 2(2), pp. 119-136. ISSN 2254-7088.

[12] HARAKÁL’OVÁ, L', 2013. Reformy Spoločnej pol'nohospodárskej politiky Európskej únie a ich vplyv na jej financovanie. Sociálno-ekonomická revue, 11(2), 7-24. ISSN 1336-3727.

[13] KAŠŤÁKOVÁ, E., 2012. Vybrané aspekty $z$ operácií v zahraničnom obchode. Bratislava: EKONÓM. ISBN 98-80-225-3409-3.

[14] KOTULIČ, R. a P. ADAMIŠIN, 2010. Analýza vývoja spoločnej pol'nohospodárskej politiky Európskej únie. In: R. KOTULIČ a P. ADAMIŠIN, eds. Prosperita polnohospodárskej výroby pre zabezpečenie trvaloudržatelného rozvoja regiónov: zborník vedeckých prác z riešenia projektu VEGA č. 1/0403/09. Prešov: Prešovská univerzita, s. 90-98. ISBN 978-80-555-0103-1.

[15] KOSTIC, V., Z. SIMONOVIC and A. KOSTIC, 2016. Advantages and Controversy of Common Agricultural and Cohesion Policy in the EU. Economics of Agriculture, 4(63), 1365-1378. ISSN 2334-8453.

[16] KUČEROVÁ, I., 2010. Hospodářské politiky v kontextu vývoje Evrópské unie. 1. vyd. Praha: Karolinum. ISBN 978-80-246-1628-5.

[17] LEBIEDZIK, M. a M. TVRDOŇ, 2007. Hospodářské politiky evropských společenstvívznik, vývoj a současnost. Karviná: Slezská univerzita v Opavě. ISBN 978-80-7248-4249.

[18] MEYN, M., 2008. Update on the CAP Health Check. [online]. [vid. 2016-07-15]. Dostupné z: www.odi.org/resources/docs/3697.pdf

[19] SEVERINI, S., A. TANTARI and G. D. TOMMASO, 2016. Do CAP direct payments stabilize farm income? Empirical evidence from a constant sample of Italian farms. Agricultural and Food Economics, 4(6), 1-17. ISSN 2193-7532.

[20] STEAD, D. R., 2007. The Mansholt Plan Forty Years On. EuroChoices, 6(3), 40-45, ISSN 1478-0917.

[21] SMUTKA, L., M. STEININGER, O. ŠKUBNA a O. MIFFEK, 2010. Vybrané aspekty agrárního sektoru ve světě. 1. vyd. Praha: Česká zemědělská univerzita v Prahe. ISBN 978-80-213-2101-4.

[22] TANKOSIC, J. V. and M. STOJSAVLJEVIC, 2014. EU Common Agricultural Policy and Pre-Accession Assistance Measures for Rural Development. Economics of Agriculture, 1(61), 195-210, ISSN 2334-8453. 